\title{
ENTREPRENEURSHIP DURING THE TIMES OF THE CORONAVIRUS PANDEMIC IN REPUBLIC OF CROATIA
}

\author{
Ivana Radlović, Anica Hunjet* and Goran Kozina
}

University North

Varaždin, Croatia

DOI: 10.7906/indecs.19.2.4

Received: 20 January 2021.

Regular article

Accepted: 14 June 2021.

\begin{abstract}
Entrepreneurship is a key driver of economic growth and a generator of employment opportunities in all modern economies across the world. Small and medium enterprises (SMEs) are the engines of modern entrepreneurship. In the Republic of Croatia, SMEs are indispensable to boost employment and economic growth. Numerous economic activities have been slowed down due to the coronavirus pandemic, and some have even been completely halted. In these extraordinary circumstances, not only in the Republic of Croatia but also all over the world, an entrepreneur must be proactive and able to promptly adapt to this new situation. The purpose of this article is to investigate the entrepreneur's position in the Republic of Croatia and to identify key problems entrepreneurs face during the coronavirus pandemic. As indicated by the research results, the coronavirus pandemic has drastically altered business activity conduction and entrepreneurship. For their businesses to survive these new, everyday challenges, many companies are forced to adapt their supply to market demands, introduce business informatization, lower the product and service prices and invest in employee education.
\end{abstract}

\section{KEY WORDS}

entrepreneurship, Republic of Croatia, European Union, pandemic, coronavirus

\section{CLASSIFICATION}

JEL: L26, O10 


\section{INTRODUCTION}

In today's economic system, small and medium enterprises are defined as the power capable of driving and influencing an improvement in certain national economic structures. In the Republic of Croatia, small and medium enterprises are possible generators of employment and economic growth [1].

Organization for Economic Cooperation and Development (OECD) indicates that entrepreneurs are the initiators of changes and growth in the market economy, and may accelerate the generation, dissemination, and implementation of innovative ideas [2]. Public assistance is mainly focused on novice entrepreneurs who do not have previous business experience [3].

When the novel coronavirus first appeared in early 2020, matters of pandemic suppression and salvation of human lives were highly prioritized. Most countries employed emergency measures like social distancing and the temporary shutdown of many business subjects, particularly in the service sector. Said emergency measures were proven to be more or less successful. As the crisis appeared, countries began to contemplate the possible consequences on the economy. Negative consequences on the economy are the result of the virus itself, as well as of the restrictive measures utilized to suppress the pandemic. Economic questions arise more and more frequently, intending to avoid an additional economic downturn that might occur due to poorly designed economic policies and measures [4].

The European Commission has activated the so-called 'General Escape Clause' for the first time in history on March $20^{\text {th }}$, 2020. This clause enables the governments of the European Union members to spend national funds on state aid to alleviate the effects of the ensued economic crisis. Additionally, a distribution of 37 billion Euros from the European Union budget has been foreseen as a means of supporting the health sector, the sustainability of the business sector, and the sustainability of workplaces.

The European Commission has been employing strong measures to strengthen the public health sector and alleviate the socioeconomic consequences the coronavirus pandemic has caused. Regions and cities of the European Union have been helping those in need by securing protective gear donations, providing treatment of infected patients abroad, and ensuring the repatriation of citizens who found themselves temporarily stuck abroad. Furthermore, the European Commission has applied complete flexibility to the fiscal rules of the European Union, has revised its rules on state aid, and established the Investment Initiative to ensure liquidity for small enterprises and the health sector. The Commission has also launched the 'Support Mitigating Unemployment Risks in Emergency' initiative, with the objective of workplace preservation and family support.

The coronavirus pandemic has caused severe damages to the global economy. It is still causing damages to this day and will continue to do so indefinitely. One can only begin to assess the total damages once the virus has been understood to a sufficient degree and once it has been relatively contained. This turn of events is not yet in sight. A short-term pandemic carries with it a certain type of consequences, whereas a longer pandemic (one that would, for example, last for over a year), has a much more pronounced impact on the economic and societal structure. The consequences of a long-term pandemic are much more severe and farreaching. A short-term pandemic can be 'covered' with financial transactions. Once the shortterm pandemic is over, this can be compensated for with a long-term production increase. Since one cannot assess exactly how long the COVID-19 pandemic will last, there are not sufficient elements to assess its total effects [5]. 
The main objective of this research was to determine to what extent the population intends to become entrepreneurs during the coronavirus pandemic. Further objectives were to determine which measures of fighting back against the coronavirus pandemic are considered the most efficient and which changes entrepreneurs must employ to adapt to this new situation.

This article is comprised of eight chapters. The first chapter is introductory. In the second chapter, an insight into the theoretical notion of entrepreneurship is given, along with a brief overview of the history of entrepreneurship. The third chapter describes the situation in the Republic of Croatia since the first COVID-infected patient appeared. The fourth chapter is based on the measures set forth by The Croatian Bank for Reconstruction and Development to fight back against the negative consequences of the coronavirus pandemic. The fifth chapter describes a package of measures introduced by the Tax Administration to maintain the liquidity of businesses. The sixth chapter lists all advantages and disadvantages of becoming an entrepreneur, with a short review on the current coronavirus pandemic, whereas the seventh chapter refers to the conducted research. This article ends with a conclusion.

\section{LITERATURE REVIEW}

Empirical research has shown that small business owners believe hard work will make them more money and will also make them happier than being an employee in someone else's company. According to the respondents, the main advantages of becoming an entrepreneur are [6]: being in control; being able to change things; being able to fulfill one's potential; unlimited income potential; social prestige, and an opportunity to pursue one's passion.

One of the advantages of becoming an entrepreneur is being in control. Owning a business gives the entrepreneur the freedom and ability to achieve his goals. True entrepreneurs do not think of their daily business activities as work [7]. The most successful entrepreneurs choose the activity they are most interested in and enjoy the most, following the advice of Harvey McKay, who said: "Find something you love to do, and you'll never have to work a day in your life" [8].

Although owning a business provides many benefits and opportunities, everyone considering entrepreneurship must be aware of the potential disadvantages: income uncertainty; risk of loss of invested capital; undefined working hours and hard work; lower quality of life in the initial phases; high level of stress; unlimited liability and discouragement [9].

Running one's own business can be a very positive experience, but also a very stressful one. Most entrepreneurs invest significant amounts of money in their businesses, leaving behind the security of a job with regular pay [10]. Often, entrepreneurs take out mortgage loans, i.e. they invest their entire properties in their business. In such cases, the failure of business would mean financial and psychological strain, which causes high levels of stress and worry [11]. Most entrepreneurs are likely to face many problems that they will not be able to solve due to a lack of knowledge [12]. At the same time, the decisions they make directly affect the success or failure of the company, as well as everyone involved in the business [13]. Entrepreneurs quickly learn that they are indistinguishable from their company and that starting a business requires commitment, discipline, and perseverance. Successful entrepreneurs also know that obstacles should not discourage them, but rather drive them to do even better [14].

Entrepreneurs are agents of change and provide a source of hope for many. To spur economic activity, entrepreneurs are needed as they come up with solutions to market problems. There are indirect effects from the crisis including export and import delays, which are affecting global trade. The coronavirus pandemic has resulted in more stress and tensions in the international business environment. The stress has come from the changes needed to stay competitive while at the same time protecting individual health. Businesses have had to 
change their models to an online format to access customers. For many businesses based on traditional face-to-face interaction, this has required a change in current business practices. Some more entrepreneurial businesses have been able to transform more quickly than others as a result of environmental changes. The reason for this is the desire of the business leaders to stay in the marketplace while respecting required regulations. This has caused much tension among businesses due to the need to adapt quickly. Entrepreneurs by definition thrive from uncertainty; however, the COVID-19 pandemic has resulted in a large amount of uncertainty from a variety of sources. This means there is still uncertainty as to whether future changes are required or whether the changes made are adequate. In the past, the majority of entrepreneurship was based on market uncertainty, but the current pandemic has included not only market but also health and social uncertainty. This combination requires strong leadership capable of adapting to the needs of their business [15].

\section{BACKGROUND}

\section{ENTREPRENEURSHIP IN REPUBLIC OF CROATIA AND COVID - 19}

The beginning of the year 2020 was characterized by terrifying news and photographs from the Chinese city of Wuhan in the region Hubei. The world started to observe the appearance of a new, until then unknown respiratory system disease from afar. Soon, this disease got an official name, COVID - 19, the corona infection. This virus belongs to the RNA virus group Coronaviridae, which causes acute respiratory infections during the winter months, and has been known since 1965. Chinese scientists have sequenced the virus quite soon and then proceeded to share their data with the rest of the world: the virus in question was a new type of RNA virus, which, until then, was not known to cause disease in humans. Genome analysis indicates that the SARS - CoV -2 has probably evolved from a type of virus often found in bats, whereas an unknown mammal has served as a potential amplifying intermediate host between bat and man [16].

The first case of a COVID - 19 infection in the Republic of Croatia has been observed on February $25^{\text {th }}, 2020$. The following chart shows the coronavirus infection growth rate in the Republic of Croatia from February $25^{\text {th }}, 2020$ to January $14^{\text {th }}, 2021$.

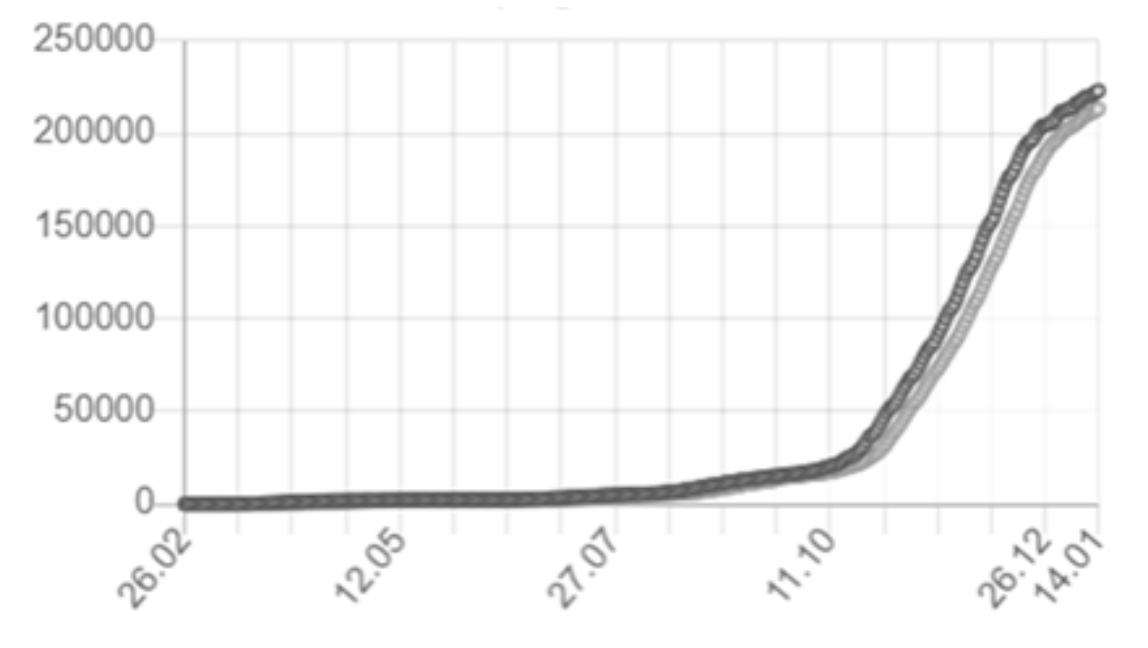

Figure 1. Number of coronavirus-infected patients in the Republic of Croatia from February $25^{\text {th }}, 2020$ to January $14^{\text {th }}, 2021$ [17].

The health crisis caused by the COVID - 19 pandemic has spread all over the world like wildfire, causing a never-before-experienced and historically unique alteration of all spheres 
of human life, including economic relations. The world has been affected by an enormous crisis with an unknown expiration date. None of the previous modern-day economic crises (The Great Depression of 1929 and The Great Recession of 2008) have ever occurred as quickly or have caused such a steep decline in global economic activity [18].

On March $17^{\text {th }}$, 2020 the Croatian government has, among the first ones in the European Union, introduced a package comprised of 63 measures, designed to aid the overall economy, maintain liquidity and preserve workplaces. The value of the said package was approximately four billion Euros. A couple of days later, a group of entrepreneurs from the "Voice of Entrepreneurs' initiative expressed their strong disapproval, claiming these measures were meek and inadequate. This initiative gained over twenty thousand members and sparked a floodtide of comments on social networks; most of them by entrepreneurs concerned for the future of their businesses. Meanwhile, after the European Commission's flexibilization of the rules on state aid, the governments of other member-states also came up with measures aimed at supporting the economy. The needs of the health sector and the needs of the small and micro-businesses were a common focus of these measures. Just like in Croatia, measures introduced by other European countries were supplemented with new, additional measures on an as-needed basis; following the effects incurred by the first package of measures and with the available funds (including funding provided by the European Commission). Aid measures were, apart from on the national level, also designed on a regional and local level (some good examples of local and regional measures are Rotterdam and Bjelovar). In addition to the content of the aforementioned measures, the speed at which they were applied was also vital, i.e. when awarding state aid, simplification and automation were crucial to the economy. Measures that are executed too late are namely as good as non-existent measures [19].

The continuation of favorable labor market trends was present in early 2020. A certain deterioration was seen in March, due to the coronavirus pandemic and the stringent containment measures. Observed quarterly, the number of employed persons (seasonally adjusted data) was slightly lower in the first quarter $(-0,1 \%)$ than in late 2019 . The number of employed persons continued to drop in April and May and was on average 3,6 \% lower than in the first quarter (Figure 2).

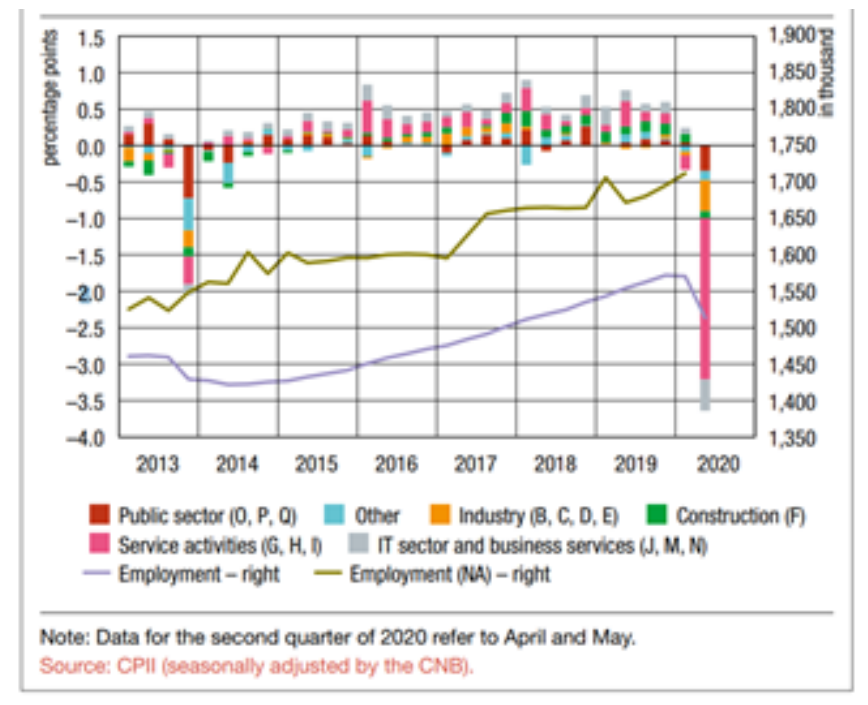

Figure 2. Employment by NCA activities, seasonally adjusted data, contributions to the quarterly rate of change [20].

Most of the noted drop was related to accommodation and food service activities, as well as to trade and transportation. Regrettably, these fields are the most vulnerable to social 
distancing measures. Unemployment continued to drop in early 2020, but then, due to an increased number of new unemployment entries into the CES register, there was an increase in the total unemployment rate in March 2020; all despite continued clearings from the register (Figure 3).

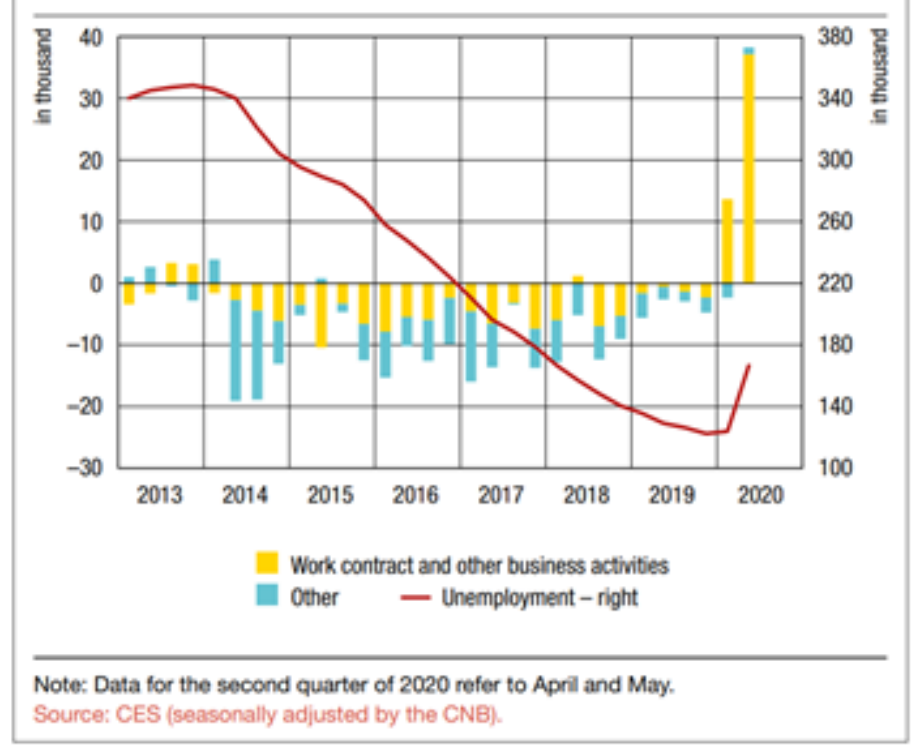

Figure 3. Total unemployment and net unemployment inflows, seasonally adjusted data [20].

The number of unemployed persons increased $8 \%$ between December 2019 and the end of the first quarter of 2020. The unemployment rate started growing at a quicker pace in April due to an increase in the number of newly unemployed persons, i.e. due to an increased number of entries into the CES register. It continued to rise in May, though at a slower pace, and was only marginally higher in late June (Figure 4).

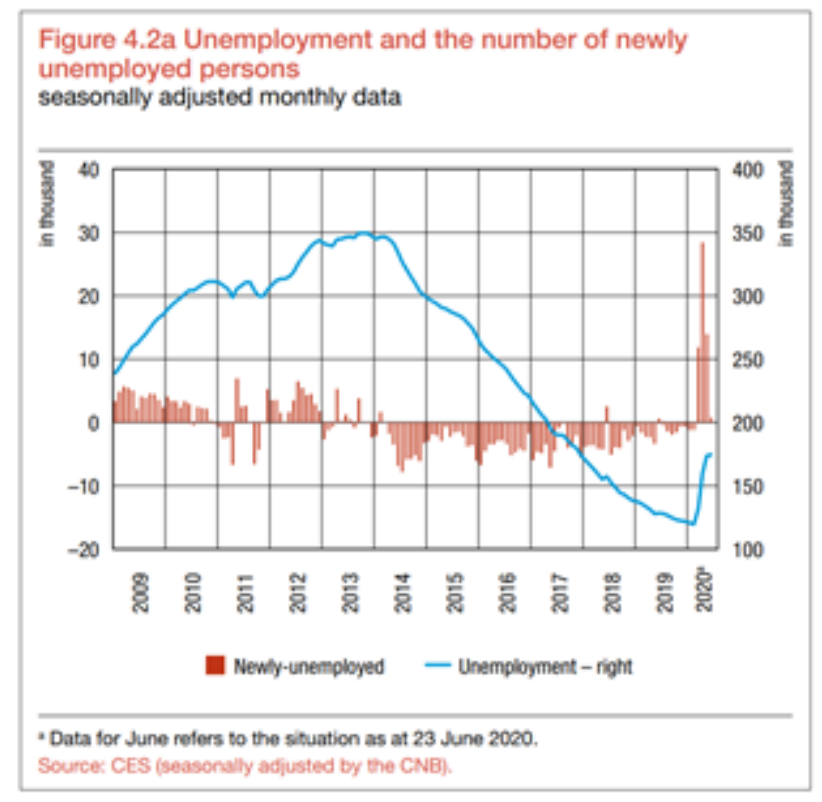

Figure 4. Unemployment and the number of newly unemployed persons, seasonally adjusted monthly data [20].

The growth of the unemployment rate was slowed down due to measures introduced by the Croatian government. These measures were designed to preserve jobs and to relax some of the restriction and lockdown rules due to a more favorable epidemiological situation [20]. 


\section{AID FOR THE ENTREPRENEURS DURING THE COVID - 19 PANDEMIC}

To alleviate the negative impacts of the COVID-19 pandemic, Croatian Bank for Reconstruction and Development has introduced new measures aimed at the preservation of the present economic activity level, business liquidity, and, most importantly, workplace conservation. With this in mind, entrepreneurs are now not only able to utilize the moratorium and reprogram their existing credit responsibilities toward the Croatian Bank for Reconstruction and Development but are also able to obtain new, favorable loans (in cooperation with a commercial bank or directly). To ensure an easier loan approval process and induce a faster recuperation process for a large number of entrepreneurs whose businesses have been negatively impacted by the COVID - 19 pandemic, insurance of credit portfolio for exporter liquidity has been introduced. This insurance has been established for exporters seeking to obtain a loan, for indirect exporters, and the tourism sector [21].

To ensure business liquidity, the Ministry of Finance has proposed an interest-free tax deferral, and/or payment of tax liabilities in installments (said tax liabilities being incurred during extraordinary circumstances). Payment of tax liabilities in installments is initiated when

Table 1. Measures conducted by the Croatian Bank for Reconstruction and Development [21]

\begin{tabular}{|c|c|c|c|c|c|}
\hline Program & $\begin{array}{c}\text { Loan } \\
\text { Potential, } \\
\text { HRK millions }\end{array}$ & Benefits & Launched & Implementation & Status \\
\hline \begin{tabular}{|l|} 
Moratorium \\
on and \\
Rescheduling \\
of Loans \\
\end{tabular} & & $\begin{array}{l}\text { Moratorium } \\
\text { duration up } \\
\text { to } 16 \text { months }\end{array}$ & 27.3.2020 & $\begin{array}{l}\text { Direct lending } \\
\text { and on-lending } \\
\text { via banks }\end{array}$ & Active \\
\hline $\begin{array}{l}\text { Working } \\
\text { Capital } \\
\text { COVID-19 }\end{array}$ & 1500 & $\begin{array}{l}\text { Interest rate } \\
\text { from } 0 \% \text { on } \\
\text { HBOR's } \\
\text { share }\end{array}$ & 30.3 .2020 & $\begin{array}{l}\text { On-lending via } \\
14 \text { banks }\end{array}$ & Active \\
\hline \begin{tabular}{|l|} 
Working Capital \\
for Wood \\
Processing and \\
Furniture \\
Production \\
\end{tabular} & 220 & $\begin{array}{l}\text { Interest rate } \\
\text { from } 0 \% \text { on } \\
\text { HBOR's } \\
\text { share }\end{array}$ & 19.5.2020 & $\begin{array}{l}\text { On-lending via } \\
14 \text { banks }\end{array}$ & Active \\
\hline \begin{tabular}{|l} 
Working \\
Capital \\
through \\
Framework \\
for Banks \\
\end{tabular} & 1200 & $\begin{array}{l}\text { Interest rate } \\
\text { reduced by } \\
0,75 \mathrm{pp}\end{array}$ & 22.5 .2020 & $\begin{array}{l}\text { On-lending via } 8 \\
\text { banks }\end{array}$ & Active \\
\hline $\begin{array}{l}\text { Working } \\
\text { Capital for } \\
\text { Rural } \\
\text { Development }\end{array}$ & 130 & $\begin{array}{l}\text { Interest rate } \\
0,5 \%\end{array}$ & 1.6 .2020 & Direct lending & Active \\
\hline $\begin{array}{l}\text { Working } \\
\text { Capital for } \\
\text { Tourism } \\
\text { Industry } \\
\end{array}$ & 600 & $\begin{array}{l}\text { Interest rate } \\
\text { from } 0 \%\end{array}$ & 15.4 .2020 & Direct lending & $\begin{array}{l}\text { Applications } \\
\text { received } \\
\text { until } 5^{\text {th }} \\
\text { June } \\
\end{array}$ \\
\hline $\begin{array}{l}\text { Insurance of } \\
\text { Loan } \\
\text { Portfolio }\end{array}$ & 5561 & $\begin{array}{l}\text { Insurance of } \\
90 \% \text { of the } \\
\text { approved } \\
\text { loan amount }\end{array}$ & 8.4 .2020 & Via 15 banks & Active \\
\hline
\end{tabular}


stabilization of business operations becomes a necessity (after cessation of extraordinary circumstances) and is completely interest-free. The main idea is to permanently induct this measure into the system using legislation alterations. This measure should be reactivated if circumstances that might affect the due tax payments, arise.

Given that this measure mostly affects the budgets of the cities, regions, and municipalities, the Croatian Institute for Health Insurance and the Croatian Pension Insurance Institute will enable interest-free loans. These loans use the allocation of budget funds to replace the aforementioned city, region, and municipality funds. Various measures about the preservation of business liquidity in the Croatian economy have been suggested. These measures have been suggested in cooperation with the Croatian Bank for Reconstruction and Development, with the Croatian Agency for SMEs, Innovations, and Investments, and with commercial banks. Croatian Bank for Reconstruction and Development has introduced a moratorium about their clients' existing credit liabilities as well as the possibility to reprogram their existing loans with a predetermined start-date on principal payments.

New loans about the so-called 'cold business operations' shall be approved in cooperation with commercial banks. Within the means of the aforementioned support measures, the introduction of the so-called standstill arrangements has been proposed, which means that the commercial banks ought to suspend their coercive collection tactics for three months. During this time, statutory interest would still be accumulated and due. New liquidity and working capital loans count among additional support measures. Payments on these loans would be due in three years. To aid the tourism sector and the Croatian export, which have been rendered most vulnerable due to the coronavirus pandemic, an increase in the scope of the export insurance fund of the Croatian Bank for Reconstruction and Development has been foreseen. This will include the tourism sector as well as business subjects that are indirect exporters (suppliers or cooperating with direct exporters) and are supposed to invite as many clients as possible to become guarantee users (insurance policies) and thus also loan users. The Croatian Agency for SMEs, Innovations, and Investments has introduced a moratorium on all due payments for micro and small loans, as well as all micro and small loans about rural development. This moratorium is in force until December $31^{\text {st }}, 2020$. Furthermore, due payments about loans with issued guarantees have also been delayed [22].

The following business subjects are entitled to reimbursement of a portion or of the entirety of their fixed costs for December of 2020: all entrepreneurs whose business activity has been halted by the decree of the Croatian Civil Protection Directorate from November $27^{\text {th }}, 2020$; all entrepreneurs whose income/revenue for December of 2020 has dropped at least $60 \%$ when compared to December of 2019; all entrepreneurs who have started their business activity in 2020 and whose income/revenue for December of 2020 has dropped at least $60 \%$ when compared to November of 2020.

Entrepreneurs who have reported an income/revenue drop ranging between $60 \%$ and $90 \%$ are entitled to a fixed cost compensation, which is to be proportionate to their income/revenue drop. Entrepreneurs who have reported a staggering $90 \%$ (or more) income/revenue drop are entitled to compensation of all fixed costs [23].

\section{METHODOLOGY}

\section{RESEARCH INSTRUMENT}

Research has been conducted using the survey research approach. The respondents who were invited to fill out the questionnaire were not solely entrepreneurs - this fact was used to determine an existence of an interest in entrepreneurship during the coronavirus pandemic. The questionnaire 
was comprised of 19 questions. 11 of the questions were multiple-choice questions, 6 of the questions employed a Likert scale, and 2 of the questions were yes/no questions. The first 3 questions were general questions used to gather basic information on the respondents.

\section{SAMPLE DESCRIPTION}

A survey was conducted on a sample comprised of 110 respondents in December of 2020. The sample was comprised of persons of different sex, age, education level, employment status, and social status to make sure that it is as representative as possible with regards to all key characteristics.

The questionnaire was filled out by $79,1 \%$ of women and $20,9 \%$ of men. The majority of the respondents were aged under $25(51,8 \%)$ or in the $26-35$ age bracket $(41 \%)$, followed by respondents in the 36-45 age bracket $(3,6 \%)$ and the $46-60$ age bracket $(3,6 \%)$. The majority of the respondents have completed a graduate study education $(35,5 \%)$, high school education $(33,6 \%)$, or an undergraduate study education $(29,1 \%)$. A smaller number of respondents have completed a postgraduate university study education (Ph.D.) $(0,9 \%)$, or a postgraduate specialist study education $(0,9 \%)$.

The main objective of this research was to determine the number of respondents who've started their businesses and the number of respondents who are considering or are not considering starting their businesses. Furthermore, the objective was to determine whether the respondents would mark the economic aid and workplace and/or liquidity preservation measures introduced by the government of the Republic of Croatia as efficient.

\section{RESULTS}

The majority of the respondents are thinking about starting their businesses (49,1\%), 44,5\% of respondents are not considering starting their businesses and 6,4\% of respondents have already started their businesses.

Analysis of the obtained data indicates that, even though a large number of respondents are not thinking about starting their businesses, the majority of respondents are considering the possibility of becoming an entrepreneur or have already started their businesses. Considering the current pandemic, these results are not surprising, especially given the fact that the coronavirus has gravely affected regular business activity.

The majority of respondents think that the measures introduced by the Republic of Croatia to aid the economy, maintain liquidity and preserve workplaces during the coronavirus pandemic are not efficient (75,5\% of respondents), whereas $24,5 \%$ of respondents think these measures are efficient. Data analysis points out that the majority of respondents think these measures are inefficient. At the time this article was created, there were 162983 unemployed persons registered with the Croatian Employment Service.

Table 2. The most efficient economic aid measures.

\begin{tabular}{|l|c|}
\hline \multicolumn{2}{|c|}{$\begin{array}{c}\text { Which measures do you think are most effective for helping economy } \\
\text { during COVID-19 pandemic? }\end{array}$} \\
\hline Short-term aid during short-time work schemes adjustment & $13,7 \%$ \\
\hline Measures for protecting workers from exposure to COVID-19 & $15,1 \%$ \\
\hline Financial aid to infected workers & $19 \%$ \\
\hline Direct crediting of companies at risk & $13,4 \%$ \\
\hline Complete tax waiver & $22,7 \%$ \\
\hline Tax payment deferrals & $16,1 \%$ \\
\hline
\end{tabular}


The majority of respondents $(22,7 \%)$ think that the most efficient economic aid measures during the coronavirus pandemic would be absolute tax exemptions, $19 \%$ of respondents believe that financial aid for ill employees would be the best aid policy, and 16,1\% chose tax deferral as the best aid policy. Furthermore, 15,1\% of respondents said that safety measures aimed at protecting the employees from exposure to the virus would be the optimal solution, $13,7 \%$ of respondents believe short-term aid for companies adjusting their work hours (short-time work schemes) would be beneficial, and $13,4 \%$ of respondents think that the best aid would be issuing direct loans to endangered companies.

Table 3: Business adaptation and the coronavirus pandemic.

\begin{tabular}{|l|c|}
\hline \multicolumn{2}{|c|}{$\begin{array}{l}\text { In which way can entrepreneurs adjust there } \\
\text { bussines model during COVID-19 pandemic? }\end{array}$} \\
\hline Investing in employee education & $12,7 \%$ \\
\hline Price reduction & $16,9 \%$ \\
\hline Adapting to market demand & $38 \%$ \\
\hline Digitalization of businesses & $32,4 \%$ \\
\hline
\end{tabular}

The majority of respondents ( $38 \%$ ) believe that in times of the coronavirus pandemic, entrepreneurs can adapt their businesses by adjusting their supply to the demands of the market, whereas another $38 \%$ believe that said adaptation can be achieved by informatization of businesses. The rest of the respondents believe that the entrepreneurs can adapt by lowering the prices of their goods and services (16,9\%), or by investing in employee education (12,7\%).

Table 4. Measures to prevent further spreading of the coronavirus.

\begin{tabular}{|l|c|}
\hline \multicolumn{2}{|c|}{ Which measures do you think are necessary to reduce the spread of COVID-19? } \\
\hline Restoran and bar clousers & $8,9 \%$ \\
\hline Kindergarten and school closures & $10 \%$ \\
\hline Restriction of the number of people in closed space surroundings & $23,7 \%$ \\
\hline Forbid public gatherings and lingering in public places & $17,9 \%$ \\
\hline Reduction of opening times for stores & $7,6 \%$ \\
\hline Working from home & $26,4 \%$ \\
\hline The limitation of intercity migration & $5,5 \%$ \\
\hline
\end{tabular}

The majority of respondents $(26,4 \%)$ believe that working from home is a measure necessary to stop the coronavirus from spreading, $23,7 \%$ of respondents think that the key measure is the restriction of the number of people who can enter enclosed spaces, and 17,9\% of respondents said that the key measure is a ban on all kinds of public gatherings. Furthermore, $10 \%$ of the respondents said the key is to close down all kindergartens and schools, 8,9\% said the most efficient measure is to close down all coffee shops and restaurants, another 7,6\% said the key is to shorten the working hours of stores and 5,5\% of respondents said the most important measure is the restriction of intercity migration.

\section{DISCUSSION AND CONCLUSION}

The main objective of this research was to determine how many people are thinking of becoming entrepreneurs during the coronavirus pandemic. Further objectives were to determine which measures of fighting back against the coronavirus pandemic are considered the most efficient and which changes entrepreneurs must employ to adapt to this new situation. The research results have shown that there is a very small number of respondents who have started their businesses, whereas nearly half of the respondents are not even thinking about starting their businesses. The respondents also believe that the measures put in place to fight back against the coronavirus pandemic are not efficient. 
This research has several limitations. The research was conducted on a sample comprised of 110 people, which is a relatively small sample. The units for the sample were chosen in a way that illustrates the basic set well. Despite this, the aforementioned limitations do not minimize the contribution of the obtained results to the observed issues. In the future, this research could be expanded to better understand the problems that modern entrepreneurs are dealing with problems related to the coronavirus pandemic, which are actively stopping potential entrepreneurs from pursuing entrepreneurial activities.

In just a couple of short months, the world had to adapt to the extraordinary new situation caused by the coronavirus pandemic. When the pandemic first started, numerous countries; the global health community included; invested great efforts into researching the possibility of discovering a vaccine that would stop the virus in its tracks. Those efforts have resulted in several potential vaccines and a start of clinical trials in a very short period. Great Britain has started administering the COVID - 19 vaccine in December of 2020. In the Republic of Croatia, the vaccination began on December $27^{\text {th }}, 2020$. After the discovery of the vaccine, the Eurozone investors demonstrated renewed vigor. The investments skyrocketed to the highest levels since the beginning of 2020, encouraged by the hope of renewed economic growth.

\section{REFERENCES}

[1] Škrtić, M. and Mikić, M.: Economic significance of Croatian entrepreneurship. In Croatian. Zbornik Ekonomskog fakulteta u Zagrebu 4(1), 191-204, 2006,

[2] Organization for Economic Cooperation and Development: Fostering Entrepreneurship. OECD, Paris, 1998,

[3] Ropega, J.: Novice and habitual entrepreneurs and external business support exploitation. Interdisciplinary Description of Complex Systems 18(2-B), 271-285, 2020, http://dx.doi.org/10.7906/indecs.18.2.14,

[4] Arčabić, V.: Corona crisis and what Croatia can learn from previous recessions. In Croatian.

In: Tica, J. and Bačić, K., eds.: Economic policy in 2021 - Croatia after the pandemic. In Croatian. Hrvatsko društvo ekonomista 48(1), 21-58, 2020,

[5] Jurčić, Lj.: Challenges of the world economy. In Croatian.

In: Tica, J. and Bačić, K., eds: Economic policy in 2021 - Croatia after the pandemic. In Croatian. Traditional Conference 28, 2020,

[6] Scarborough, N.M.; Wilson, D.L. and Zimmerer, T.W.: Effective small business management: an entrepreneurial approach.

Pearson Prentice Hall, Upper Saddle River, 2009,

[7] Heck, R.K., et al: The family's dynamic role within family business entrepreneurship. In: Poutziouris, P.Z.; Smyrnios, K.X. and Klein, S.B., eds.: Handbook of Research on Family Business. Edward Elgar Publishing, Cheltenham, pp.80-105, 2006,

[8] Škrtić, M. and Mikić, M.: Entrepreneurship.

Sinergija d.o.o., Zagreb, 2011,

[9] Pejic Bach, M.; Skok, M.M. and Suša, D.: Determinants of entrepreneurial intentions in ICT industry: gender and country of origin perspective.

Naše gospodarstvo/Our economy 62(1), 37-45, 2016, http://dx.doi.org/10.1515/ngoe-2016-0004,

[10] Moric, I.: Clusters as a factor of rural tourism competitiveness: Montenegro experiences. Business Systems Research Journal 4(2), 94-107, 2013, http://dx.doi.org/10.2478/bsrj-2013-0015,

[11]Zahra, S.A. and George, G.: The net-enabled business innovation cycle and the evolution of dynamic capabilities.

Information Systems Research 13(2), 147-150, 2002,

http://dx.doi.org/10.1287/isre.13.2.147.90, 
[12] Jurčić, M.; Lovrenčić, S. and Kurnoga, N.: Croatian defense industry competitiveness cluster: knowledge management and innovation perspective.

Business Systems Research Journal 11(1), 59-72, 2020,

http://dx.doi.org/10.2478/bsrj-2020-0005,

[13] Dumičić, K.; Bregar, L. and Žmuk, B.: Statistical methods use in small enterprises: relation to performance.

Business Systems Research Journal 5(3), 37-48, 2014, http://dx.doi.org/10.2478/bsrj-2014-0018,

[14] Mencer, I.: Strategic management: enterprise development management. In croatian. TEB poslovno savjetovanje d.o.o., Zagreb, 2012,

[15]Ratten, V.: Coronavirus and international business: An entrepreneurial ecosystem perspective.

Thunderbird International Business Review 62(5), 629-634, 2020, http://dx.doi.org/10.1002/tie.22161,

[16] Štajduhar D.: Coronavirus disease 2019: a summary of publications for workers in public health and primary health care.

http://www.stampar.hr/sites/default/files/Aktualno/novosti/covid_19_sazetak_2020_03_30.pdf, accessed $15^{\text {th }}$ December 2020,

[17]-: Number of coronavirus-infected patients in the Republic of Croatia from February $25^{\text {th }}, 2020$ to January $14^{\text {th }}, 2021$,

https://www.koronavirus.hr, accessed $14^{\text {th }}$ January 2021,

[18] Čavrak, V.: Macroeconomics of the COVID-19 crisis and how to approach its solution. In Croatian.

Faculty of Economics, University of Zagreb, Zagreb, 2020,

[19] Alpeza, M.: Coronary measures to fight for the sustainability of the economy in seven EU countries.

Ekonomski fakultet u Osijeku \& CEPOR, 2020,

[20] Croatian National Bank: Macroeconomic Developments and Outlook. https://www.hnb.hr/documents/20182/3398618/eMKP 08.pdf/6d99f12b-6a7b-2743-df23-cc417e 0c964a, accessed $18^{\text {th }}$ January 2021,

[21]Croatian Bank for Reconstruction and Development: Assistance to entrepreneurs affected by the covid-19 epidemic. In Croatian.

https://www.hbor.hr/tema/pomoc-poduzetnicima-za-ublazavanje-negativnih-posljedica-nastalihpandemijom-covid-19-virusa-koronavirusa, accessed $14^{\text {th }}$ December 2020,

[22]-: Government measures. In Croatian.

https://www.koronavirus.hr/vladine-mjere/mjere-pomoci-gospodarstvu/126, accessed, $15^{\text {th }}$ December 2020 ,

[23] Porezna uprava: Tax information related to the emergency caused by the spread of the covid-19 virus. In Croatian.

https://www.porezna-uprava.hr/Stranice/COVID 19 informacije.aspx, accessed $15^{\text {th }}$ December 2020. 